- carbon dioxide and methane and the more esoteric fluorinated chemicals.

The data should help researchers trying to measure and track greenhouse-gas emissions, as well as those studying natural carbon cycles. As scientists pin down exactly where anthropogenic carbon emissions are coming from, Marland says, they can separate out carbon uptake and emissions by plants and soils. "The better we understand both the magnitude and distribution of human emissions, the better we understand what is happening in the biosphere."

\section{THE USUAL CULPRITS}

Some database searches produce very familiar results. Carbon dioxide makes up about $95 \%$ of the greenhouse-gas emissions logged (although if emissions from agriculture and other sectors in the full US inventory are included, that proportion would drop to around $83 \%$ ). The state with the largest overall emissions is Texas, which logged 387 million tonnes of carbon dioxide equivalent in 2010. And power plants overshadow any other stationary sources of greenhouse gases, accounting for about three-quarters of emissions in the inventory (see 'The gas tracker').

But there are also some eye-opening statistics. Just $2.5 \%$ of the facilities that have submitted data to the EPA are responsible for $45 \%$ of the emissions, for example. And almost all of the United States' emissions of trifluoromethane (also known as HFC-23), a potent greenhouse gas, come from just two facilities - the Honeywell International plant in Baton Rouge, Louisiana, and the Dupont manufacturing plant in Louisville, Kentucky. Since 1990, US producers have voluntarily reduced by about $85 \%$ their emissions of trifluoromethane, which is a by-product of the manufacture of the refrigerant and chemical feedstock chlorodifluoromethane.

The flood of data does not mean that scientists can stop measuring greenhousegas emissions in the atmosphere. Pieter Tans and his team at the National Oceanic and Atmospheric Administration's Earth System Research Laboratory in Boulder, Colorado, measure greenhouse-gas plumes from major facilities through a network of tall monitoring towers, for example. The annual totals in the database will certainly help to improve their atmospheric models, he says, but monitoring how emissions vary over the course of hours and days is still vital.

Totalling those real-time measures should also provide a way to verify the companies' annual estimates. "The hypothesis is that these are correct emissions estimates," Tans says. "We can test that to see whether what is being reported is consistent with actual observations." "

\title{
EDUCATION
}

\section{Evolution advocate turns to climate}

\section{Education centre known for battling creationists aims to help science teachers convey understanding of global warming.}

\section{BY SUSAN YOUNG}

S tudents walking out of classrooms when global warming is mentioned; teachers pressured to change lesson plans to avoid the subject or portray it as speculative rather than a matter of scientific consensus. For Eugenie Scott, the stories and anecdotes fit a familiar pattern. Scott is executive director of the National Center for Science Education (NCSE) an organization based in Oakland, California, with a reputation for doggedly defending the teaching of evolution in US classrooms. But a growing impression that climate science is facing a similar struggle, together with entreaties from educators and textbook authors, has helped to convince her that the NCSE should expand its mandate to include the politically charged issue of global warming.

"I think we can make an important contribution," says Scott. "If teachers understand that there is a place that they can go to for help, we can use some of the expertise that we've gained over the years dealing with evolution to apply to this related problem."

A recent survey in the United States suggests that there is indeed a problem. From August to October 2011, the nation's National Earth Science Teachers Association (NESTA) queried Earth- and space-science teachers about their experiences of climate-change education. Depending on the region, $25-30 \%$ of respondents reported that students, parents, administrators or other community members had argued with them that climate change is not happening or that it is not the result of human activity. Some school boards and state legislators have threatened to require educators to 'teach the controversy' about climate change - a term coined in relation to evolution that amounts to presenting a scientific theory as one of various possible viewpoints.

Many of the teachers surveyed have strong science backgrounds and professional experience related to climate change. But "when you look at what the teachers are facing across the country, it goes way beyond science", says Roberta Johnson, executive director of NESTA, based in Boulder, Colorado. "It goes into areas of political debate."

In a 16 January announcement, the NCSE says that it will offer support to educators facing ideological opposition when teaching climate change, providing advice on how to present the underlying science. The strategy mirrors its approach to evolution, which includes clarifying for students why science is an appropriate tool for understanding the natural world. "This perspective is also important in helping people to understand the reasons why scientists overwhelmingly accept climate change," the NCSE says in a mission statement describing the new effort.

The statement also says that the NCSE will not take a position on what, if anything, should be done to counteract global warming or mitigate its effects. "What to do about it ranges widely and gets outside of the strict science and into policy issues in which many, many variables are going to have to be considered," says Scott. "We are not a policy think tank; we don't have expertise in this area."

But such policy neutrality may not prevent science teachers from being challenged in the classroom. "The core issue is not whether global warming "When you look is happening, or at what the teachers are facing across the country, it goes way beyond science." whether humans are involved, but whether it is a crisis," says James Taylor, a research fellow at the Heartland Institute, a libertarian think tank based in Chicago, Illinois, that opposes the regulation of carbon emissions (see Nature 475, 440-441; 2011).

Scott acknowledges that there is more to teaching climate change than explaining the science clearly. "We need to be aware of the fact that people are very emotionally concerned about these issues," she says. If people feel threatened ideologically, politically or economically, "all the science in the world won't convince them". She adds that the NCSE will also help teachers to understand the views of parents and others who oppose the teaching of climate change.

"Knowing the motivations behind a parent's views can help a teacher come up with a solution or response that might assuage that parent's concerns and let their kid remain in the classroom," says Scott. . 